\title{
Introduction: revisiting the relationship between gender and war: reflections on theory, research, activism and policy
}

Simona Sharoni and Julia Welland

\section{CONTEXT}

Gender has always been central to the practice and representation of war as well as to efforts to oppose war and rebuild societies in its aftermath. Feminist theorizing about gender and war, however, has only gained visibility and legitimacy in both the academy and among policymakers in the past three decades. The result is an impressive body of interdisciplinary literature that has gone far beyond its original home in disciplines such as International Relations. As the contributions to this Handbook underscore, feminist-informed scholarly debates on gender and war have expanded to include sociologists, anthropologists, historians, economists, geographers, and communication and media scholars, as well as scholars based in interdisciplinary fields like gender and sexuality studies and ethnic studies. Furthermore, this growing field of study is informed not only by academic research but also by discussions among policymakers and activists. As such, the literature on gender and war, and this Handbook in particular, are designed both for students and faculty committed to understanding the gendered dimensions of war. All the chapters in the Handbook include information relevant to activists, advocates and policymakers who want to reflect on their experiences and explore best practices to address the gendered aspects of war and political violence.

The evolution of feminist thinking about war can be generally understood in terms of three distinct phases: first, making women visible in discussions of war; second, focusing on 'gender' rather than 'women' and challenging the automatic association of men with war and women with peace; and third, analysis of gender in relation to other identities and structured inequalities that shape and are shaped by war. The first phase of feminist theorizing on gender and war dates back to the 1980s and reflects efforts to make women visible in studies of war and its multiple effects. The literature that emerged during this period was primarily 
influenced by the work of Jean Bethke Elshtain and Cynthia Enloe. In her seminal work Women and War, Elshtain (1987) demonstrated the significance of gender to the distinction between the 'protector' and the 'protected'. Grounding her theory in a historical analysis of war narratives, Elshtain argued that most accounts of war describe courageous men ('just warriors') taking up arms to defend vulnerable women ('beautiful souls'). Around the same time, Cynthia Enloe, who, like Elshtain, had a doctorate in Political Science, began to explore the effects of war and militarization on women's lives. Enloe's Does Khaki Become You? The Militarization of Women's Lives (1983) and Bananas Beaches and Bases: Making Feminist Sense of International Politics (1989) inspired scholarship on the relevance of gender to understanding not only war but also international politics more generally.

As Elshtain argued, traditionally, and in most societies, men are the ones who have been expected to fight wars, while women and children have been relegated to the homefront (Elshtain, 1987). Over the past three decades, however, literature about women's experiences of war has flourished, expanding to give accounts of the multiple roles and experiences women have in wartime. The result is a more nuanced body of work about women as victims and opponents of wars as well as active fighters and perpetrators of violence, including sexualized and genderbased violence (Cohen, 2013; Sjoberg and Gentry, 2007; MacKenzie, 2009).

Starting in the 1990s, inspired by postmodern sensibilities, feminist theorizing about war became more complex, to warn against the tendencies to conflate the term 'gender' with 'women' and to essentialize gender differences; viewing men as warriors and women as peacemakers, feminist scholars said, overlooked differences among both men and women (for example, see: Runyan and Peterson, 1993; Sylvester, 1994). Feminists today have moved beyond simply comparing and contrasting the experiences of men and women in war. Instead, current consensus is that because gender is pivotal to identity formation and transformation, and to divisions of power and labor across cultures and contexts, it contributes greatly to the understanding of war and its aftermath. Gendered analyses of war and its aftermath are no longer focused on demonstrating that gender matters, but are instead designed to reveal when and how gender impacts the politics and practices of war.

The contemporary feminist scholarship on gender and war reflected in this volume is both interdisciplinary and international in scope, including original theorizing, research and policy-relevant recommendations. The chapters are divided into four sections addressing the gendered aspects related to the conduct of war, its impacts, opposition to war, and war's 
aftermath. Contributors to this collection share the premise that gender is central to the understanding of war and its effects, albeit not in terms of conventional or simple-minded binaries. Building upon this claim, they draw on and contribute to, at least one, but often several, of the following bodies of literature:

- feminist theorizing about violence, power, peace, security and justice;

- feminist intersectional literature on gender and war;

- feminist scholarship on men, masculinities and militarism;

- feminist analyses of the relationship between political violence and sexualized, gender-based violence; and

- critical feminist scholarship on gender mainstreaming in relation to gender and war.

By approaching war as a key site for the materialization of gendered power relations, contributors to the Handbook underscore that gender not only shapes assumptions about who fights and who is fought for, but is also integral to the enactment and justification of militaristic campaigns as well as to opposition to war. As scholars continue to unearth and analyze gendered myths, practices and power relations that enable violence in the international arena, our understandings of war continue to deepen.

\section{FEMINIST THEORIZING ABOUT VIOLENCE, POWER, PEACE, SECURITY AND JUSTICE}

Feminists have long been engaged in rethinking violence, power, peace, security and justice in an effort to capture the gendered dimensions of the experiences and struggles of women and men in conflict zones around the world. Feminist rethinking of the concepts key to the understanding of war have emerged from research on the roles of women and men in conflicts, as well as in the processes designed to bring about their just and peaceful resolution. Feminist reformulations of these central concepts represent an important step toward feminist theorizing about gender during war and in its aftermath.

\section{Violence}

Early feminist theorizing on violence addressed mainly direct, physical violence, and associated violence with men and nonviolence with women 


\section{Handbook on gender and war}

(Eisler, 1989; Kirk, 1989; Boulding, 1992). These conceptualizations became more complex as feminists began to articulate connections between violence against women and structural and cultural forms of violence including the war system (Sharoni, 1994; Agathangelou, 2004; Sachs et al., 2007; Shalhoub-Kevorkian, 2009). The shift in feminist thought to theorizing differences and articulating intersections resulted in more nuanced conceptualizations of violence. Feminist conceptualizations of violence tend to be context-specific, grounded in particular struggles. They address systemic violations of people's rights and dignity based on gender, race, ethnicity, class and sexual orientation, among other dimensions, and based on the intersections of these dimensions. The resulting definitions of violence offer scholars and policymakers conceptual tools to help look beyond the symptoms of violence to examine its root causes. In most cases, these include structured inequalities and/or asymmetrical power relations, which tend to propel and fuel violence.

\section{Power}

Feminist reconceptualizations of power are based on a critique of the paradigm of power politics that has dominated the field of international politics and diplomacy for almost a century. Feminists take issue with conventional conceptualizations of power grounded in competition, control, dominance and violence, which often result in zero-sum power struggles that escalate into large-scale wars (Hartsock, 1983; Eisler, 1989; Boulding, 1992).

The powerful feminist slogan 'the personal is political' has inspired many feminist attempts to redefine power as agency, manifesting itself in examples of women's activism in conflict areas. As a conflict transforms their lives, women feel empowered to shape its course and outcome (Sharoni, 2001). More recently, feminists influenced by Michel Foucault have joined other poststructuralist theorists in treating power as a discourse. According to this formulation, power is everywhere, producing and shaping the meaning of everything we do (Shepherd, 2008). If everything we can see is shaped by and in turn shapes power relations, then everything we see is gendered, raced and imbued with structured inequalities. This complex and multifaceted conceptualization of power has much to contribute to the analysis and resolution of conflicts. 


\section{Security}

Feminist scholars and activists have long challenged the tendency to conflate security with national security, which takes for granted state power and the existing political status quo. They raised serious concerns with the overwhelming priority of states to invest funds and energies in the military and then rely upon the threat of using the army to 'protect' the collective citizenry (Harris and King, 1989; Ruddick, 1989). Feminist case studies from around the world support the argument that nationstates, far from providing security, as is often assumed, have become a primary source of insecurity, especially for women and other underprivileged groups (Harris and King, 1989; Sharoni, 1994; Agathangelou, 2004; Scuzzarello, 2008). Based on this evidence, feminists have concluded that the more preoccupied a government is with its military power as a means to provide what it calls 'national security', the more insecure are its vulnerable citizens (Enloe, 1989, 2007; Sharoni, 1994; Abdo and Lentin, 2002; Sachs et al., 2007). Feminist reexaminations of the dominant security discourses point out that 'security' now operates more as an instrument of mystifying rhetoric than a concept with any analytical precision. Furthermore, appeals to the need for security have often been used (by states) to justify highly violent military campaigns and territorial expansions. The post-September 11, 2001 era has not only provided ample evidence to support this proposition but has also inspired some brilliant, highly original feminist scholarship (Russo, 2006; Faludi, 2007; Jiwani, 2009; Riley et al., 2008). Feminist reconceptualizations of security suggest a shift from thinking about security in mutually exclusive, zero-sum ways (i.e., 'national security') to focusing instead on 'human security' or 'global security'.

Many feminist engagements go beyond the critique of 'national security' to question the very idea of 'security' as a totalizing patriarchal concept that cannot accept any disorder, incoherence or lack of control. In contrast, feminists suggest that security is always partial, elusive and mundane (Sylvester, 1989; Tickner, 1992). Feminist interpretations of security do not treat it as an absolute end or as a scarce resource that needs to be possessed, but rather as a complex process that needs to be negotiated and renegotiated as change occurs in different historical and sociopolitical circumstances (Tickner, 1992).

Feminist scholars are also challenging previous definitions of security from feminists and peace activists who saw it as an outcome that can be achieved rather than as a discourse. In these older formulations, the term 'security' is often used interchangeably with the term 'peace', and both assume the end of armed conflict (Jabri, 1996; Mackay, 2004; Shepherd, 
2008). Today, feminist reconceptualizations of security seek to transcend what Laura Shepherd (2008, p. 127) refers to as the 'theoretical tautology of defining conflict as the absence of security and security as the absence of conflict'. Along these lines, feminists like Megan MacKenzie (2012) have argued that security should not be defined in a vacuum but rather in relation to other key concepts such as development and conflict transformation, which are crucial to igniting wars, negotiating peace agreements and rebuilding conflict-torn societies.

\section{Peace}

Early feminist theorizing on peace and conflict defined peace as more than the absence of physical violence, insisting that 'real' peace must involve the absence of all forms of violence, including structural and cultural violence, and the presence of justice and equality for all (Boulding, 1992; Reardon, 1993, Confortini, 2006). Cynthia Enloe suggested a more modest definition that emerges from 'the conditions of women's lives', and involves 'women's achievement of control over their lives' (1989, p. 538). Building on this definition and drawing on examples from the ongoing conflicts and political processes in Israel, Palestine and the North of Ireland, Sharoni argues, 'the transition from conflict to post-conflict realities is more complex and multi-faceted than a simple departure from a negative situation (i.e. conflict) to a positive one (i.e. peace)' (2001, p. 174). While these definitions are both subtle and more complex than conventional conceptualizations of peace, peace is still conceived as a tangible good that is preferable to war.

Contemporary feminists suggest that peace has no fixed meaning and should be viewed as a political discourse (Shepherd, 2008). The definition of 'peace', as with any other term, reflects the political position of the person or group who defines it, as well as the particular sociopolitical context within which it is constructed. Different definitions of peace often reveal different degrees of commitment to social and political change or compliance with the prevailing status quo of power relations, including the gendered divisions of power and labor in a particular society. This formulation urges feminist scholars not to assume but to probe whose lives the signing of a peace agreement is likely to improve, and what structures of inequality it is going to dismantle or even uphold.

\section{Justice}

Feminist efforts to theorize justice in the context of war and its aftermath are relatively new. Early feminist theorizing of justice was based on a 
redefinition of peace not simply as the end of political violence but also the eradication of inequality and the adoption of policies designed to achieve gender justice (Ackerly and Attanasi, 2009; Fraser, 2013). It has evolved out of the project of gendering human rights and recognizing women's rights as human rights. In recent years, feminist theorizing of justice has been central to the expansion of scholarship on transitional justice. As Catherine O'Rourke points out, 'feminist engagement with human rights and transitional justice has always worked on two fronts, seeking both the protection of the human rights framework for violations against women, while also seeking to challenge and redefine the narrow understandings of violations that fall within the human rights frame' (2013, p. 37). Feminists have insisted that a redefinition of justice must be informed by the lived experiences of women in conflict zones, paying close attention to gender-based harms and taking into legal consideration their severity and short- and long-term impacts (Bell, 2009; Bell and O'Rourke, 2007; Buckly-Zistel and Stanley, 2011).

In sum, feminists have long realized that the processes of refining and implementing feminist interpretations of central concepts in the field cannot be limited to the confines of the academy (Giles, 2008). Contemporary feminists now agree that research on conflict and peacemaking needs to be grounded in the highly diverse experiences of women and men in conflict zones. By insisting on redefining concepts such as violence, peace, security and justice in order to account for the daily lives and struggles of women around the world, feminists and other critical scholars have expanded traditional definitions of these concepts to include not only gender, race and class inequalities, abuses of human rights, and attacks on cultural and ethnic identities, but also questions of development, environmental degradation and ecology (Agathangelou, 2004; Agathangelou and Ling, 2004; Philipose, 2007; Lind, 2010). Most contributors to this collection draw on the new feminist definitions of violence, power, peace, security and justice; with chapters by Tania Kaiser, Caron Gentry, Laura Sjoberg, Laura Shepherd and Caitlin Hamilton, Megan MacKenzie and Catherine O'Rourke all critically engaging with the theoretical debates among feminists about the political implications of the new definitions of violence, power, peace, security and justice. Moreover, the section on Gender and Opposition to War relies heavily on the new feminist definitions of these key concepts. Through detailed case studies, focused on both historical and contemporary activism, Ilene Feinman, Cami Rowe, Simona Sharoni, Jennifer Pedersen, Jodi Burkett and Jennifer Chan examine the message, strategies and efficacy of anti-war movements and peace campaigns from Israel, Palestine, Japan, Liberia and the United States. 


\section{FEMINIST INTERSECTIONAL LITERATURE ON GENDER AND WAR}

Feminists have long argued that gender identities and gender relations are socially constituted through complex interrelated processes. As a result, the meanings and practices associated with being a man or a woman and the rigidity of the categories themselves are highly variable across cultures, contexts and times. Understanding the existing linkages between different, usually interlocking, systems of domination and oppression and between different cartographies of struggle is central to the analysis of conflicts and the exploration of prospects for their resolution. Feminists have also called attention to the fact that sexism, racism, colonialism and homophobia are examples of interlinked systems of oppression that reinforce one another because they share a logic of domination, of $u s$ versus them, thus, legitimizing the power of one group over another and justifying the use of violence against 'the other'.

Feminist intersectional analysis emerged in the context of and in relation to social movements led by people of color, gays and lesbians, women and working-class people. By 'intersections', feminists referred to the interconnectedness of gendered identities, structures of domination, discrimination, oppression, exploitation and violence (Davis, 1983; Crenshaw, 1991; Mohanty, 2003). These theories grew out of the experiences of women who felt that their histories and struggles were not reflected in the agenda of the feminist movement in Europe and North America. Women of color, lesbians, working-class women and women in the Global South argued that their experiences as women need to be examined in relation to other experiences shaped by colonialism, their race, culture, ethnicity, class and sexual orientation, among other dimensions.

Women of color in the US insisted that they could only be part of a feminist movement if it incorporated the notion of difference and did not force them to choose between their struggle against sexism and their commitment to end racism (Moraga and Anzaldúa, 1983; Hooks, 1984, 1990; Collins, 1991; Anzaldúa and Keating, 2002). Further, women in the Global South who were involved in a dual struggle for national liberation and for women's liberation, began to explore and address the linkages between gender oppression and the broader political context within which it unfolds (Jayawardena, 1986; Mohanty, 1991).

Taking difference into account and applying feminist theories of intersections to the analysis of war involves paying attention to how gender intersects with other markers of identity in a particular locale. 
Thus, feminist intersectional analysis can be used to uncover the distribution of power within systems and relationships, and especially to reveal how unequal distribution of power and privilege can sow the seeds for and fuel political violence and war.

Feminist intersectional analysis has clearly informed several chapters in this Handbook, including those authored by Tania Kaiser, Joyce Jacobsen, Joane Nagel and Lindsey Feitz, Christopher Hills, Simona Sharoni, Julia Welland, Caron Gentry and Jennifer Chan. These authors demonstrate skilfully how age, social class, race, sexual orientation and geographical location enhance the analysis of the gendered dimensions of war and its aftermath. Similarly, as the chapters authored by Dan Berkowitz and Qi Ling and by Linda Steiner illustrate, attention to other relevant identities greatly impacts the ways gender is portrayed in news media about war and political violence.

\section{FEMINIST SCHOLARSHIP ON MEN, MASCULINITIES, AND MILITARISM}

Over the years, feminists have written extensively about men and the effects of men's identities and behavior on women, society and international politics (Tickner, 1992; Runyan and Peterson, 1993; Sylvester, 1994, Zalewski and Parpart, 1998 and 2008; Hooper, 2001; Whitworth, 2004). Nevertheless, critical feminist scholarship on masculinity and especially on the experiences of men during war and its aftermath is relatively young. Early feminist engagement with the topic emphasized men and masculinity's innate or natural proclivity towards violence and thus to war (for example see Ruddick, 1983; Reardon, 1985; Hartstock 1989). As a result, men and masculinity were 'often inadvertently still treated as unproblematic, undifferentiated wholes' (Hooper, 2001, p. 42).

Contemporary feminist scholarship on men and masculinities, however, seeks to 'problematize masculinities, the hegemony of men, and the subject of man within the theories and practices of international relations' (Zalewski, 1998, p. 1) (see for example Zalewski and Parpart, 1998 and 2008; Hooper, 2001). Within this expanding body of literature, the relationship between men, militarism and particular conceptions of masculinity has received the most sustained attention from feminists.

Building on Elshtain and Enloe's recognition that particular constructions of masculinity and femininity are required for wars to be waged, a significant body of feminist work now focuses on the production, operation and effects of military and militarized masculinities across the globe (for example, see: Whitworth, 2004; Belkin, 2012; Eichler, 2011; 
Duncanson, 2013; Welland, 2013). Much of this work draws on and challenges Raewyn Connell's (1995) understanding of hegemonic masculinity. Connell argued that masculinities and femininities should be understood as relational concepts and urged scholars to examine the relationships both between masculinity and femininity, and between dominant and subordinate masculinities: 'relations of alliance, dominance and subordination ... constructed through practices that exclude and include, that intimidate, [and] exploit' (Connell, 1995, p. 77). Drawing on the work of Antonio Gramsci, Connell coined the term 'hegemonic masculinity' to denote 'one form of masculinity rather than others that is culturally exalted' (Connell, 1995, p. 77). While hegemonic masculinity works to reinforce male power and advantage, it simultaneously subordinates, and even culturally stigmatizes, those masculinities that fall outside its proscribed boundaries. In the Global North, hegemonic masculinity is often associated with whiteness, heterosexuality, socioeconomic privilege and higher education.

Feminist scholarship on men and masculinities as they relate to militarization and war reveals how traits and characteristics such as strength, dominance, courage and aggression are promoted not only by the armed forces and insurgency groups that rely on soldiers, but also by the communities that often adopt traditional conceptions of masculinity and femininity during war (Cockburn and Zarkov, 2002). Feminists have used both the concepts of 'military masculinities' and 'militarized masculinities' to understand the processes and practices of turning men into soldiers. Military/militarized masculinities are understood as being central to the perpetuation of violence in international politics, with the valorization of militarized and masculinized traits and the concomitant denigration of people who fail to embody them contributing towards occurrences of wartime sexual violence (Baaz and Stern, 2009), torture (Richter-Montpetit, 2007) and ongoing sexual discrimination and harassment within national militaries (Woodward and Winter, 2007).

While most contributors to the Handbook reference scholarship on men, masculinities and war, Victoria Basham, Julia Welland, Paul Higate, Mary Manjikian and Caron Gentry offer in-depth analyses of the role of particular understandings of masculinities in specific contexts and situations. These authors suggest that the patterns underscoring the relationship between men and war have changed dramatically over time as a direct result of the shifts in the policies and execution of modern warfare. Megan MacKenzie, Catherine O'Rourke and Christopher Hills discuss the relevance of the masculinities and militarism 
literature in the aftermath of war, especially in the context of Disarmament, Demobilization and Reconstruction (DDR) and transitional justice programs.

\section{FEMINIST ANALYSES OF THE RELATIONSHIP BETWEEN POLITICAL VIOLENCE AND SEXUALIZED, GENDER-BASED VIOLENCE}

Feminist research has pointed to the ways that violence against women results from complex sociopolitical and cultural institutions that normalize the use of violence (Reardon, 1985). A careful examination of the proliferation of small arms and their role in intimate-partner violence revealed higher rates of violence against women in militarized societies, often during and in the aftermath of wars. Feminists have called attention to the fact that militaristic interpretations of 'national security' and a significant presence of armed military and police personnel paradoxically heighten the sense of insecurity of women and minority groups (Cockburn and Zarkov, 2002; Sharoni, 2008). Additionally, it also appears that societal levels of militarism and rates of sexual assault, rape and intimate-partner violence prior to the escalation of a political conflict impacts upon gender-based violence at the height of the conflict (Sharoni, 2016). Likewise, the prevalence of violence against women during conflict tends to impact on the life experiences and safety of women in post-conflict societies (Cockburn, 2012).

Although the extensive use of rape during wartimes attracted little scholarly or media attention until the early 1990s, there is ample historical evidence that the use of mass rape is not merely a modern phenomenon (Buss, 2009). Throughout history, militarism has enabled and normalized gender-based crimes perpetrated against women during fighting. While sexual assault and rape are present in many societies in peacetime, the prevalence and magnitude of sexual attacks on women increases dramatically in wartime, with some cases involving the deliberate and systematic rape of thousands of women. Accounts from Africa, Asia, the Americas, the Middle East and Europe reveal that large-scale sexual violence was present in at least 51 countries over the last 20 years (Bastick et al., 2007).

Detailed accounts by UN agencies and by international humanitarian and human rights non-governmental organizations, which focused on the impact of armed conflict on women, confirm the prevalence of multiple rapes of individual women in many conflict zones (Leatherman, 2011; Kirby, 2013). The systematic sexual violence was sometimes carried out 
by various groups of men, including gangs of boys and men, local and regional militias, and organized armed forces, including UN peacekeepers (Whitworth, 2004). Women were raped in their homes, in refugee camps and in prison. In some militias that included women, they were held in sexual servitude by the fighting men. In other cases, sexual slavery was institutionalized (Yoshimi, 2002). The prevalence of sexual assault in the military and the lack of accountability for perpetrators is now a noted area of concern in the United States (Hunter, 2007; Nagel, 2014).

Though rape and sexual violence have been prevalent aspects of war throughout history, the phrase 'rape as weapon of war' became widely used by researchers, policymakers and media analysts only during the 1990s, as evidence surfaced about widespread use of rape and sexual assault in Bosnia (Salzman, 1998). Attention to this issue revealed the prevalence of gender-based sexualized violence in other conflict zones including Liberia, Rwanda, the Democratic Republic of Congo (DRC) and Sierra Leone, among others (Bastick et al., 2007; Baaz and Stern, 2013; Cohen, 2013). The recognition by foreign policy establishments that rape and other forms of gender-based violence are in fact tactics of war led to the categorization of these crimes as war crimes. As a result, gender-based violence has been a prominent issue, in recent years, on the agenda of both the United Nations and numerous human rights organizations (Sharlach, 2000; Kirby, 2013 and 2015).

A small, but growing, scholarship is centered on men's experiences during war, particularly in relation to their exposure to sexualized violence as victims (for example Sivakumarian, 2007; Nagel and Feitz, 2008). Several contributors to the Handbook, including Laura Sjoberg, Mayesha Alam, Myriam Denov, Alexandra Ricard-Guay, Amber Green and Christopher Hills address the interplay between political violence and gender-based, sexualized violence. In doing so, these authors examine the prevalence of gender-based and sexualized violence during war as well as its lingering effects in the aftermath of war.

\section{GENDER MAINSTREAMING AND WAR}

Unlike anti-discrimination laws that seek to achieve equality between men and women, 'gender mainstreaming starts from the recognition that gender differences shape policy processes and outcomes' (True, 2003, p. 369, original emphasis). Adopted as a global strategy for achieving gender equality at the 1995 Fourth World Conference on Women in Beijing, gender mainstreaming has achieved widespread endorsement 
from individual governments, regional supra-state bodies such as the European Union and Nordic Council of Ministers, and global governance institutions such as the UN and the Organisation for Economic Co-operation and Development (Andersen, 1993; Razavi and Miller, 1995; United Nations, 1997; Council of Europe, 1998; True, 2003).

The impact of gender mainstreaming on matters of international security and war is most notably demonstrated in the passing in 2000 of the UN Security Council Resolution 1325 on 'Women, Peace and Security'. Approved unanimously at a special meeting of the UN Security Council (UNSC), it was the first time the UNSC had discussed women and gender in relation to peace and security (Cohn, 2008). The resolution

... seeks to mainstream an official sensitivity to gender within UN institutions, as well as the decision-making processes of all governments, with regard to conflict resolution, peacekeeping, and peacebuilding; to include more women in all institutions involved in the prevention, management, and resolution of conflict; and to protect the rights of women, particularly with regard to ending gender-based violence, in wartime. (Pratt, 2013, p. 773; see also UNSC, 2000)

Also in 2000, the Department of Peacekeeping published a report titled Mainstreaming a Gender Perspective in Multidimensional Peace Operations (United Nations, 2000), which reiterated 1325's basic argument that women's involvement in peacekeeping missions enhanced peace negotiations. In the years following 1325, a number of UNSC resolutions were passed aimed at reinforcing the goals of the resolution, increasing the role of women in peacebuilding, and further protecting women and girls from wartime sexual violence. ${ }^{1}$

Many feminists heralded UNSCR 1325 as a feminist success story. Not only did the resolution's explicit recognition of gendered power relations challenge realist conceptions of security at the highest levels, but its focus on women as active participants of the peace process and postconflict reconstruction challenged conceptions of women as only the passive victims of violent international practices (Cohn et al., 2004; Hill et al., 2004). As Carol Cohn has written: 'It is amazing that the world's largest international security institution has now publicly declared that attention to gender is integral to "doing security" (Cohn et al., 2004, p. 139).

The initial celebration of UNSCR 1325 notwithstanding, feminists have raised critical questions about both its implementation and longterm transformative potential. ${ }^{2}$ Among the concerns raised is whether the resolution can achieve its goals if the UN itself remains structured in a way that prevents words from being efficiently turned into actions. Cohn, 
who has been involved with the movement that ushered in the resolution, has identified several barriers to 1325's implementation and the degree to which gender mainstreaming can be effectively initiated. She notes that structural and logistical barriers to the successful implementation of Resolution 1325 include a lack of commitment to enforce the resolution, a failure to allocate the necessary financial support to gender programs, and a basic inability to think critically about how to enact gender mainstreaming in different contexts (Cohn in Hill et al., 2004, pp. 9-10). Other feminist critics of UNSCR 1325, informed by intersectional and postcolonial feminist critiques, questioned its celebration as an accomplishment of the feminist movement globally (Harrington, 2011; Pratt, 2013). Nicola Pratt (2013) views the resolution not as a positive step towards the transformation of women's (and men's) lives in conflict, but as a re-inscription of racial-sexual boundaries along the lines of the political economy of imperialism. In Pratt's reading, 'advocates of 1325 have become "securitizing actors," in that their discourses help to construct the threat of "dangerous brown men" and (re)affirm the legitimacy of international intervention in order to "secure" women and girls in conflict zones' (2013, p. 779). Pratt concludes that while 1325 may be a strategic tool for women activists in conflict zones, it simultaneously contributes to the legitimacy and normalization of gendered, raced and sexualized hierarchies (2013, p. 780). While several contributors to this Handbook, including Laura Shepherd, Caitlin Hamilton, Megan MacKenzie and Christopher Hills have explicitly criticized gender mainstreaming policies and their implementations, others, like Soumita Basu, recognize the groundbreaking impact of gender mainstreaming and its contribution to public debates and policies designed to advance gender equality and justice during and in the aftermath of war.

\section{CONCLUSION}

This Handbook is not designed to offer a definitive account of existing knowledge on gender and war but rather to contribute to ongoing conversations on the topic. Taken together, the authors in the collection raise thought-provoking questions that broaden and deepen feminist engagement with the gendered dimensions of war and its aftermath. Building on the contributions of feminist scholars who first paid attention to the workings of gender in international affairs in the 1980s, the chapters in this collection span multiple disciplines and make use of a wide range of methodological approaches. There are three areas in particular to which the Handbook contributes. 
First, the authors in this collection engage in original feminist research and theorizing. Working through a range of theoretical approaches and using a multitude of methods, including historical records, field interviews, popular culture and policy documents, authors reveal how gender shapes the conduct of war and its multiple impacts, as well as resistance and opposition to war and the challenges of rebuilding war-torn societies. Because feminist research often involves asking questions that may have previously been dismissed as unimportant or irrelevant, exploring sites that have been otherwise ignored, and being concerned with what is presumed to be the banal or mundane, it has frequently made use of methods or ways of knowing dismissed by the discipline the researcher works within. In this Handbook feminist insights have been leveled on the early twentieth century to the contemporary period; across Europe, North America, Africa and the Middle East; and on a range of activities including Hollywood films, familial relations and protest movements in numerous countries. The scope of the Handbook and the number of insights garnered serve to remind us to remain always vigilant to the operations of gender at the personal and international, micro and macro, levels.

Second, while theoretically rich and a clear contribution to the academic field of feminist research on/about war, the chapters in this Handbook have obvious important policy relevance. Traversing topics such as policy decisions regarding who can and cannot fight, the economic and familial effects of war, and the 'post-conflict' moment, research within this Handbook reveals the uneven and gendered effects of war. With national governments, supra-national bodies and international institutions and organizations increasingly recognizing the importance of gender to international affairs, there must be greater effort for dialogue between academics and activists/practitioners. A number of authors draw on their own experiences of negotiating and traversing the divide between academic and practitioner communities, reflecting on the ways in which their research impacts on their practice and vice versa.

Third, and perhaps most importantly, the Handbook opens up new avenues for research and questioning. While the chapters in this volume shine a light on and bring visibility to particular places, bodies and types of violence, there are simultaneous silences and erasures that need to be addressed. Feminism is at its strongest when it remains open to new voices and perspectives, and when it is responsive to those who have felt excluded from its project. Increasingly, this means listening to those who have historically been excluded from setting the parameters of the debate or who have seen their own concerns sidelined or ignored, including 
people in the Global South, members of Lesbian Gay Bisexual Transgender communities, and racial and ethnic minorities, immigrants and refugees.

As we celebrate the breadth and depth of existing scholarship on gender and war, we continue to be mindful of key challenges facing us. The production and dissemination of new knowledge about gender and war depends to a great extent on our willingness to recognize and address the tensions between the Global North and Global South and between academics, policymakers, relief workers, activists, and, most importantly, those whose lives have been shattered by war and political violence. By engaging critically with the new knowledge presented in this Handbook while paying attention to gaps, silences and unanswered questions, readers can shape not only the next volume of scholarship on this topic but also the future of policy, advocacy and activism on gender and war. Above all, this Handbook is an invitation to readers to join a vibrant, transnational, critical conversation about feminist theorizing and a gender-sensitive analysis of war.

\section{NOTES}

1. Subsequent UNSC resolutions are as follows: '1820 (passed in 2008), which recognizes sexual violence in conflict as a matter of international security; 1888 (of 2009), which provides for mechanisms to strengthen the implementation of UNSCR 1820; 1889 (of 2009), which addresses obstacles to women's participation in peace processes and peace building; and 1960 (of 2010), which further strengthens calls to implement 1888 and 1889' (Pratt, 2013, p. 772).

2. For a critical engagement with UNSCR 1325 see the 2011 special edition of International Feminist Journal of Politics (vol. 13, no. 4), edited by Nicola Pratt and Sophie Richter-Devroe.

\section{REFERENCES}

Abdo, Nahla Abdo and Ronit Lentin (2002), Women and the Politics of Military Confrontation, Indiana University Press.

Ackerly, Brooke and Katy Attanasi (2009), 'Global feminisms: theory and ethics for studying gendered injustice', New Political Science, 31 (4): 543-55.

Agathangelou, Anna M. (2004), The Global Political Economy of Sex: Desire, Violence, and Insecurity in Mediterranean Nation States, Palgrave Macmillan.

Agathangelou, Anna M. and Lily H.M. Ling (2004), 'Power, borders, security, wealth: lessons of violence and desire from September 11', International Studies Quarterly, 48 : 517-38.

Andersen, Mary (1993), 'The concept of mainstreaming: experience and change', in Mary Andersen (ed.), Focusing on Women: UNIFEM's Experience of Mainstreaming, UNIFEM, pp. 1-32. 
Anzaldúa, Gloria E. and Analouise Keating (2002), This Bridge We Call Home: Radical Visions for Transformations, Routledge.

Baaz, Maria Eriksson and Maria Stern (2009), 'Why do soldiers rape? Masculinity, violence and sexuality in the armed forces in the Congo (DRC)', International Studies Quarterly, 53: 495-518.

Baaz, Maria Eriksson and Maria Stern (2013), Sexual Violence as a Weapon of War? Perceptions, Prescriptions, Problems in the Congo and Beyond, Zed Books.

Bastick, Megan, Karin Grimm and Rachel Kunz (2007), Sexual Violence in Armed Conflict: Global Overview and Implications for the Security Sector, Centre for the Democratic Control of Armed Forces.

Belkin, Aaron (2012), Bring Me Men: Military Masculinity and the Benign Façade of American Empire 1898-2001, Hurst.

Bell, Christine (2009), 'Transitional justice, interdisciplinarity, and the state of the "field" or "non-field", International Journal of Transitional Justice, 3 (1): 5-27.

Bell, Christine and Catherine O'Rourke (2007), 'Does feminism need a theory of transitional justice? An introductory essay', International Journal of Transitional Justice, 1 (1): 23-44.

Boulding, E. (1992), The Underside of History: A View of Women Through Time (2 vols), Sage.

Buckly-Zistel, Susanne and Ruth Stanley (2011), Gender in Transitional Justice, Palgrave Macmillan.

Buss, Doris (2009), 'Rethinking "rape as a weapon of war"', Feminist Legal Studies, 17: $145-63$.

Cockburn, Cynthia (2012), Antimilitarism: Political and Gender Dynamics of Peace Movements, Palgrave Macmillan.

Cockburn, Cynthia and Dubravka Zarkov (eds) (2002), The Postwar Moment: Militaries, Masculinities and International Peacekeeping, Lawrence and Wishart.

Cohen, Dara Kay (2013), 'Explaining rape during civil war: cross-national evidence (1980-2009)', American Political Science Review, 107 (3): 461-77.

Cohn, Carol (2008), 'Mainstreaming gender in UN security policy: a path to political transformation?', in Shirin Rai and Georgina Waylen (eds), In Global Governance: Feminist Perspectives, Palgrave Macmillan.

Cohn, Carol, Helen Kinsella and Sheri Gibbings (2004), 'Women, peace and security, Resolution 1325', International Feminist Journal of Politics, 6 (1): 130-40.

Collins, Patricia Hill (1991), Black Feminist Thought: Knowledge, Consciousness, and the Politics of Empowerment, Routledge.

Confortini, Catia (2006), 'Galtung, violence, and gender: the case for a peace studies/ feminism alliance', Peace and Change, 31 (3): 333-67.

Connell, Raewyn (1995), Masculinities, Polity.

Council of Europe (1998), Gender Mainstreaming: Conceptual Framework, Methodology and Presentation of Good Practices, Final report of activities of the group of specialists on mainstreaming (Rapporteur Group on the Equality Between Women and Men, GR-EG), Committee of Ministers, 26 March.

Crenshaw, Kimberlee (1991), 'Mapping the margins: intersectionality, identity politics, and violence against women of color', Stanford Law Review, (43): 1241-99.

Davis, Angela (1983), Women, Race and Class, Random House.

Duncanson, Claire (2013), Forces for Good? Military Masculinities and Peacebuilding in Afghanistan and Iraq, Palgrave Macmillan.

Eichler, Maya (2011), Militarizing Men: Gender, Conscription, and War in Post-Soviet Russia, Stanford University Press.

Eisler, Riane (1989), The Chalice and the Blade: Our History, Our Future, Harper and Row.

Elshtain, Jean Bethke (1987), Women and War, University of Chicago Press. 
Enloe, Cynthia (1983), Does Khaki Become You? The Militarization of Women's Lives, University of California Press.

Enloe, Cynthia (1989), Bananas Beaches and Bases: Making Feminist Sense of International Politics, University of California Press.

Enloe, Cynthia (2007), Globalization and Militarism: Feminists Make the Link, Rowman \& Littlefield.

Faludi, Susan (2007), The Terror Dream: Myth and Misogyny in an Insecure America, Picador.

Fraser, Nancy (2013), 'Reframing justice in a globalizing world', Fortunes of Feminism: From State-Managed Capitalism to Neoliberal Crisis, Verso, pp. 189-209.

Giles, Wenona (2008), 'Reflections on the women in conflict zones network: lessons from the past and forward-looking possibilities', International Feminist Journal of Politics, 10 (1): 102-12.

Harrington, Carol (2011), 'Resolution 1325 and post-cold war feminist politics', International Feminist Journal of Politics, 13 (4): 557-75.

Harris, Adrienne and Ynestra King (eds) (1989), Rocking the Ship of State: Toward a Feminist Peace Politics, Westview.

Hartsock, Nancy (1983), 'Money, sex, and power: a theory for women?', in Linda Nicholson (ed.), Feminism/Postmodernism, Routledge, pp. 157-75.

Hartstock, Nancy (1989), 'Masculinity, heroism and the making of war', in Adrienne Harris and Ynestra King (eds), Rocking the Ship of the State: Towards a Feminist Peace Politics, Westview.

Hill, Felicity, Carol Cohn and Cynthia Enloe (2004), UN Security Council Resolution 1325 Three Years On: Gender, Security and Organizational Change, Roundtable discussion at the Boston Consortium on Gender, Security and Human Rights, Boston MA, 20 January.

Hooks, Bell (1984), Feminist Theory From Margin to Center, Pluto.

Hooks, Bell (1990), Yearning: Race, Gender and Cultural Politics, Turnaround.

Hooper, Charlotte (2001), Manly States: Masculinities, International Relations, and Gender Politics, Columbia University Press.

Hunter, Mic (2007), Honor Betrayed: Sexual Abuse in America's Military, Barricade Books.

International Feminist Journal of Politics (2011), Special edition examining UNSCR 1325 on Women, Peace and Security, 13 (4), edited by Nicola Pratt and Sophie RichterDevroe.

Jabri, Vivienne (1996), Discourses on Violence: Conflict Analysis Reconsidered, Manchester University Press.

Jayawardena, Kumari (1986), Feminism and Nationalism in the Third World, Zed Books.

Jiwani, Yasmin (2009), 'Helpless maidens and chivalrous knights: Afghan women in the Canadian press', University of Toronto Quarterly, 78 (2): 728-44.

Kirby, Paul (2013), 'How is rape a weapon of war? Feminist international relations, modes of critical explanation and the study of wartime sexual violence', European Journal of International Relations, 19 (4): 797-821.

Kirby, Paul (2015), 'Acting time; or, the abolitionist and the feminist', International Feminist Journal of Politics, 17 (3): 508-13.

Kirk, Gwen (1989), 'Our Greenham Common: not just a place but a movement', in Adrienne Harris and Yenestra King (eds), Rocking the Ship of State: Toward a Feminist Peace Politics, Westview.

Leatherman, Janie L. (2011), Sexual Violence and Armed Conflict, Polity.

Lind, Amy (2010), Development, Sexual Rights and Global Governance, Routledge.

Mackay, Angela (2004), 'Training the uniforms: gender and peacekeeping operations', in Afshar Haleh and Deborah Eade (eds), Development, Women and War: Feminist Perspectives, Oxfam GB, pp. 100-108. 
MacKenzie, Megan H. (2009), 'Securitization and desecuritization: female soldiers and the reconstruction of women in post-conflict Sierra Leone', Security Studies, 2 (18): 241-61.

MacKenzie, Megan H. (2012), Female Soldiers in Sierra Leone: Sex, Security, and Post-Conflict Development, NYU Press.

Mohanty, Chandra Talpade (1991), 'Cartographies of struggle: third world women and the politics of feminism', in Chandra Talpade Mohanty et al. (eds), Third World Women and the Politics of Feminism, Indiana University Press.

Mohanty, Chandra Talpade (2003), Feminism without Borders: Decolonizing Theory, Practicing Solidarity, Duke University Press.

Moraga, Cherríe and Gloria Anzaldúa (1983), This Bridge Called My Back: Writings by Radical Women of Color, Kitchen Table.

Nagel, Joane (2014), 'Rape and war: fighting men and comfort women', in Mindy Stombler, Dawn Baunach, Wendy Simonds, Elroi Windsor and Elisabeth Burgess (eds), Sex Matters: The Sexuality and Society Reader, W.W. Norton, pp. 641-8.

Nagel, Joane and Lindsey Feitz (2008), 'The militarization of gender and sexuality in the Iraq war', in Helena Carreiras and Gerhard Kümmel (eds), Women in the Military and in Armed Conflict, VS Verlag für Sozialwissenschaften, pp. 201-25.

O'Rourke, Catherine (2013), Gender Politics in Transitional Justice, Routledge.

Philipose, Liz (2007), 'The politics of pain and the end of empire', International Feminist Journal of Politics, 9 (4): 607-16.

Pratt, Nicola (2013), 'Reconceptualizing gender, reinscribing racial-sexual boundaries in international security: the case of UN Security Council Resolution 1325 on "Women, Peace and Security", International Studies Quarterly, 57: 772-83.

Razavi, Shahar and Carol Miller (1995), 'Gender mainstreaming: a study of efforts by the UNDP, the World Bank and the ILO to institutionalize gender issues', United Nations Institute for Social Development Occasional Paper No 4.

Reardon, Betty (1985), Sexism and the War System, Teachers College.

Reardon, Betty (1993), Women and Peace: Feminist Visions of Global Security, State University of New York Press.

Richter-Montpetit, Melanie (2007), 'Empire, desire and violence: a queer transnational feminist reading of the prisoner "abuse" in Abu Ghraib and the question of "gender equality", International Feminist Journal of Politics, 9 (1): 58-9.

Riley, Robin, Chandra Talpade Mohanty and Minnie Bruce Pratt (eds) (2008), Feminism and War: Confronting US Imperialism, Zed Books.

Ruddick, Sara (1983), 'Preservative love and military destruction: Reflections on mothering and peace', in Joyce Trebilcot (ed.), Mothering: Essays on Mothering and Peace, Littlefield Adams.

Ruddick, Sara (1989), Maternal Thinking: Toward a Politics of Peace, Beacon.

Runyan, Anne Sisson and V. Spike Peterson (1993), Global Gender Issues, Westview.

Russo, Ann (2006), 'The Feminist Majority Foundation's campaign to stop gender apartheid', International Feminist Journal of Politics, 8 (4): 557-80.

Sachs, Dalia, Amalia Sa'ar and Sarai Aharoni (2007), “"How can I feel for others when I myself am beaten?" The impact of the armed conflict on women in Israel', Sex Roles, 57 (7-8): 593-606.

Salzman, Todd A. (1998), 'Rape camps as a means of ethnic cleansing: religious, cultural, and ethical responses to rape victims in the former Yugoslavia', Human Rights Quarterly, 20 (2): 348-78.

Scuzzarello, Sarah (2008), 'National security versus moral responsibility: an analysis of integration programs in Malmo, Sweden', Social Politics: International Studies in Gender, State and Society, 15 (1): 5-31. 
Shalhoub-Kevorkian, Nadera (2009), Militarization and Violence against Women in Conflict Zones in the Middle East: A Palestinian Case-Study, Cambridge University Press.

Sharlach, Lisa (2000), 'Rape as genocide: Bangladesh, the Former Yugoslavia, and Rwanda', New Political Science, 22 (1): 89-102.

Sharoni, Simona (1994), 'Homefront as battlefield: gender, military occupation and violence against women', in Tamar Mayer (ed.), Women and the Israeli Occupation: The Politics of Change, Routledge, pp. 121-37.

Sharoni, Simona (2001), 'Rethinking women's struggles in Israel-Palestine and in the North of Ireland', in Caroline Moser and Fiona Clark (eds), Victims, Perpetrators or Actors? Gender, Armed Conflict and Political Violence, Zed Books, pp. 85-98.

Sharoni, Simona (2008), 'De-militarizing masculinities in the age of empire', The Austrian Political Science Journal (special issue: 'Counter/Terror/Wars: Feminist Perspectives'), 37 (2): 147-64.

Sharoni, Simona (2016), 'Militarism and gender-based violence', in Nancy Naples, Maithree Wickramasinghe and Angela Wong Wai Ching (eds), The Wiley-Blackwell Encyclopedia of Gender and Sexuality Studies, Wiley Blackwell, pp. 1-9.

Shepherd, Laura J. (2008), Gender, Violence and Security: Discourse as Practice, Zed Books.

Sivakumarian, Sandesh (2007), 'Sexual violence against men in armed conflict', European Journal of International Law, 18 (2): 253-76.

Sjoberg, Laura and Caron E. Gentry (2007), Mothers, Monsters, Whores: Women's Violence in Global Politics, Zed Books.

Sylvester, Christine (1989), 'Patriarchy, peace, and women warriors', in Linda R. Forcey (ed.), Peace: Meanings, Politics, Strategies, Praeger.

Sylvester, Christine (1994), Feminist Theory and International Relations in a Postmodern Era, Cambridge University Press.

Tickner, J. Ann (1992), Gender in International Relations: Feminist Perspectives on Achieving Global Security, Columbia University Press.

True, Jacqui (2003), 'Mainstreaming gender in global public policy', International Feminist Journal of Politics, 5 (3): 368-96.

United Nations (1997), Report of the Economic and Social Council for 1997, A/52/3, 18 September.

United Nations (2000), Mainstreaming a Gender Perspective in Multidimensional Peace Operations, Lessons Learned Unit: Department of Peacekeeping Operations, July.

United Nations Security Council (2000), Resolution 1325, Adopted by the Security Council on its 4213th meeting on 31 October.

Welland, Julia (2013), 'Militarised violences, basic training, and the myths of asexuality and discipline', Review of International Studies, 39 (4): 881-902.

Whitworth, Sandra (2004), Men, Militarism \& UN Peacekeeping: A Gendered Analysis, Lynne Rienner.

Woodward, Rachel and Trish Winter (2007), Sexing the Soldier: The Politics of Gender in the Contemporary British Army, Routledge.

Yoshimi, Yoshiaki (2002), Comfort Women: Sexual Slavery in the Japanese Military During World War II, Columbia University Press.

Zalewski, Marysia (1998), 'Introduction: from the "woman" question to the "man" question in international relations', in Marysia Zalewski and Jane Parpart (eds), The 'Man' Question in International Relations, Westview, pp. 1-13.

Zalewski, Marysia and Jane Parpart (eds) (1998), The 'Man' Question in International Relations, Westview.

Zalewski, Marysia and Jane Parpart (eds) (2008), Rethinking the Man Question: Sex, Gender and Violence in International Relations, Zed Books. 